\title{
Trematodon (Bryopsida: Bruchiaceae) in Australia: unravelling the conundrum.
}

\author{
Helen P. Ramsay ${ }^{1,2,3}$, R.D. Seppelt ${ }^{2}$ and A.J. Downing ${ }^{2}$ \\ ${ }^{1}$ National Herbarium of New South Wales, Royal Botanic Gardens and Domain Trust, \\ Mrs Macquaries Road, Sydney, NSW 2000, Australia. \\ ${ }^{2}$ Downing Herbarium, Department of Biological Sciences, Macquarie University, NSW 2109, Australia. \\ ${ }^{3}$ author for correspondence: hpramsay@ozemail.com.au
}

\begin{abstract}
Following a critical re-examination and evaluation of Australian taxa of the genus Trematodon, three species formerly considered endemic, T. baileyi Broth., T. brachyphyllus Müll. Hal., and T. longescens Müll. Hal., together with the New Caledonian endemic T. longifolius Broth. \& Paris in Broth., are illustrated for the first time and reduced to synonymy of T. longicollis Michx.
\end{abstract}

\section{Introduction}

Around 160 taxa have been described for the genus Trematodon Michx. worldwide but only about 25 species are currently accepted (data from www.tropicos.org, accessed 21 September 2017). Recent classifications include the genus Trematodon in the family Bruchiaceae (Goffinet et al. 2009, 2012). Nine species have been reported from Australia (Streimann \& Klazenga 2002) and type collections of five of these are from Australia: T. flexipes Mitt. in Hook.f. from Tasmania; T. amoenus (Müll. Hal.) I.G.Stone \& G.A.M.Scott from New South Wales; T. baileyi Broth. from tropical north-east Queensland; T. brachyphyllus Müll. Hal. from Queensland; and T. longescens Müll. Hal. from New South Wales and Queensland.

Species of Trematodon are terrestrial colonisers of soil, earth banks, or soil over rock. Fruiting plants are easily identified to genus by the elongate apophysis or neck of the capsule, but individual species may be difficult to place. However, there can be considerable variation in capsule length relative to seta length, and in length of the capsule neck relative to the spore-bearing urn, within and among species.

The gametophytes of many Trematodon species are similar and there are few definitive features to separate taxa in the absence of mature sporophytes. Relative width of the costa in the leaf and subula, costal anatomy, and structure of the leaf margins (unistratose or bistratose) may provide useful distinguishing characters. Because of the way the leaf lies when mounted under a cover glass, these features are best observed in a series of thin transverse sections of leaves. The importance of investigating a series of leaf sections is explained later.

As part of a revision of the family Bruchiaceae for the Flora of Australia it became apparent that a number of taxa reported and referrable to what may be best described as the T. longicollis Michx. complex needed critical re-evaluation. This group of taxa included T. baileyi (Brotherus 1891), T. brachyphyllus and T. longescens (Mueller 1898). Examination of types, where available, and many specimens in Australian herbaria has helped elucidate the status of the Australian taxa. 


\section{The Genus Trematodon}

Although Trematodon is represented in the bryoflora of many regions and continents, there has been no world-wide revision of the genus. Regional revisions have been carried out for North America (Crum \& Anderson 1981), South Africa (Magill 1981), India (Gangulee 1987), Japan (Noguchi 1987; Iwatsuki \& Suzuki 2006), Malesia (Eddy 1988), New Guinea (Norris \& Koponen 1990) and China (Cao \& Gao 1988), but none previously for Australia.

The gametophytes of many Trematodon taxa are similar. The stems are branched or unbranched, with rhizoids arising from the base. Basal leaves are usually very short and scale-like but the leaves increase rapidly in size upwards, developing a sheathing base and becoming subulate. Perichaetial leaves have a broader base, which ends gradually or abruptly in a long acuminate subula that may be more or less erect to flexuose to strongly contorted or crispate. Leaf margins in the sheathing base are unistratose while those of the subula are partially or fully bistratose in some species. The length of the leaf subula relative to the basal portion, particularly in perichaetial leaves, varies between species being as much as two or more times the length of the base. The costa may be relatively narrow in the base but occupy most of the subula width. At least locally the relative width of the costa in the subula, costal anatomy, anatomy of the leaf and margins, may all provide useful identifying features and are discussed more fully later.

In the absence of mature sporophytes, individual species may be difficult, if not impossible, to identify with certainty. While it is essential to have mature sporophytes for identification, ratios of urn to neck length, capsule length to seta length, may also show considerable variation within a given taxon.

\section{The Trematodon Iongicollis complex in Australia}

Trematodon longicollis Michx. Flora Boreali-Americana 2: 289. 1803.

Type citation: In arenosis Carolinae Michaux

Type: Eastern North America, "In arenosis Carolinae", Michaux. Not located.

Illustrations: Bartram (1939: pl.2, Fig. 26); Fleischer (1977: 296, Fig. 49a-g - as T. acutus); Crum \& Anderson (1981: 163, Fig. 67H-L); Magill (1982: 116, Figs 21-29, 30); Kumar (1985: 15, pl.III); Gangulee (1987: 232, Fig. 106); Eddy (1988: 106, Fig. 98a-f); Cao \& Gao (1988: 325-326, 328, Figs 1-3); Norris \& Koponen (1990: 5-7, Fig. 1a-g); Zander (2007: 436); Noguchi (1987: 137 Fig. 52A); Figures 1, 8.

Autoicous. Plants small to medium sized, in loose yellow-green tufts. Stems simple, 1-8 mm long. Leaves small and scale-like below, becoming progressively larger above, $1.0-3.0(-8.0) \mathrm{mm}$ long, erect-spreading, \pm flexuose when moist, from an ovate-oblong sheathing base $1.0-2.0 \mathrm{~mm}$ long, contracting gradually or abruptly to a broad flexuose channelled subula $2.0-6.0 \mathrm{~mm}$ long, subula contorted or crispate when dry; apex denticulate; margins unistratose in base, bistratose to occasionally with tristratose patches in subula; lamina cells in subula and upper part of sheathing base \pm irregular in outline, subquadrate, quadrate, short-rectangular to irregularly hexagonal, \pm equidimensional to $c .3 \times 1$, becoming more elongate and broader to $c .5-10 \times 1$ in leaf base, thinwalled throughout; costa narrow throughout, occupying c. 1/3 width of subula but not filling it at the apex, subpercurrent. In section, costa with weakly defined bands of substereid cells between epidermal-like thinwalled cells adaxially and abaxially in the leaf base, and with a central row of deuter or guide cells between the subsclereids in the subula.

Perigonia terminal on short lateral branches. Perichaetia terminal. Perichaetial leaves larger than stem leaves, 5.0-8.0 mm long, subulate from an elongate ovoid sheathing base, subula 1-3× longer than base, \pm crispate when dry. Seta slender, erect to \pm flexuose, $8.0-30.0 \mathrm{~mm}$ long. Capsule slender, arcuate, $5.0-7.0 \mathrm{~mm}$ long, urn oblong-cylindric, neck 2-2.5x length of urn, \pm twisted when dry, strumose at base, stomata confined to neck; exothecial cells rectangular, 3-7×1, with thick curved lateral walls; annulus compound, revoluble, of 2 or 3 layers of rectangular enlarged cells; operculum from a conic base obliquely long-rostrate, the rostrum often as long as urn; peristome single, teeth reddish, linear-lanceolate from a low basal membrane, $330-430 \mu \mathrm{m}$ long, deeply cleft into two filaments or joined and perforate, margins pale papillose, tips of filaments often joined, pale whitish; calyptra cucullate. Spores subreniform to rounded, baculate-verrucose, lacking a trilete scar, $15-25 \mu \mathrm{m}$ in diameter. 


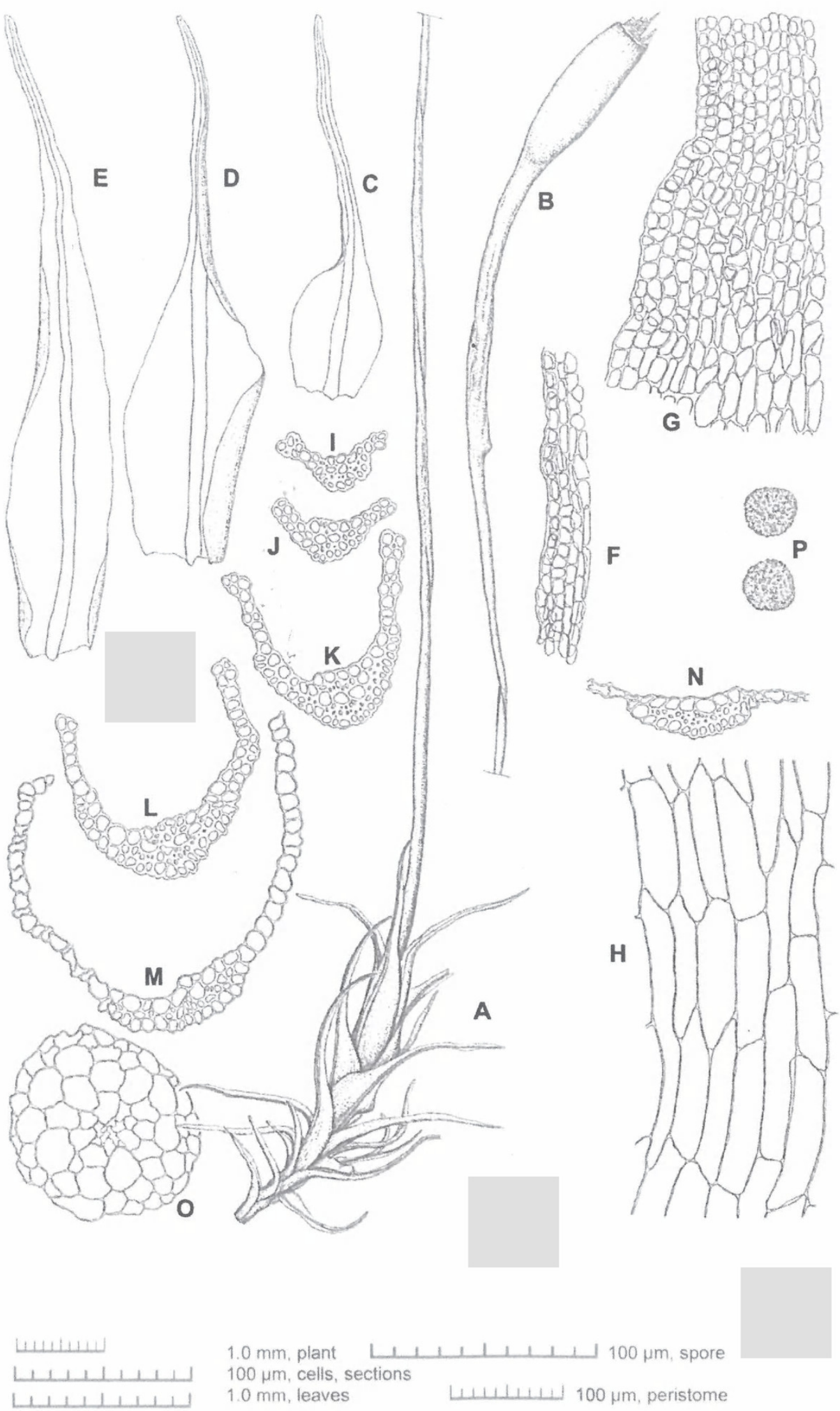

Figure 1. Trematodon longicollis. A. Fruiting plant B. detached capsule; C-D. Stem leaves; E. Perichaetial leaf. F. Cells of subula margin. G. Cells of shoulder region of leaf base. H. Cells of leaf base; I-K. Transverse sections of subula. L-M. Transverse sections of basal part of leaf from near point of attachment. N. Section of costa; O. Stem section. P. Spores. Scale bars: $1.0 \mathrm{~mm}$ for plants and leaves; $100 \mu \mathrm{m}$ for cells, sections and spores.

Drawn from: Japan, Musci Japonicae Exsiccatae Ser. 21. No. 1048 (Hattori Botanical Laboratory) by R.D. Seppelt. 
Distribution: Known in Australia from Western Australia (WA, New South Wales (NSW), Queensland (Qld), and Victoria (Vic). Prior to our studies, the distribution of T. longicollis in Australia was given as WA and Vic. (Streimann \& Klazenga 2002). The Western Australian records were based on two non-fruiting collections from East Kimberley, identified by Stone (1985: 476) as T. acutus Müll. Hal., a synonym of T. longicollis. Although capsules are absent the identification appears correct and specimens examined by us (MEL 1047743) have the typical leaf structure of $T$. longicollis.

Selected Australian collections named as T. longicollis: Western Australia: East Kimberley: on track to Bungle Bungles, $57 \mathrm{~km}$ from Turkey Creek, K.F. Kenneally 9203 [as T. acutus sterile] (PERTH 204465); Samin Mining Camp, $19 \mathrm{~km}$ E of Osmund Valley Palms Yard, W.A. Chesterfield 237, J.H. Willis \& S.J. Forbes, 15 May 1984 [sterile] (MEL 104774A); Queensland: Mount Bellenden Ker, I.G. Stone 12131, 27 May 1975 [male and female plants] (MEL-2212870); South Kennedy: Wet Tropics, Near Innisfail, Nerada Tea Plantation, I.G. Stone, 15 Aug 1979 (MEL-2224961); Cook: Cape Tribulation, I.G.Stone 21950, 28 May 1984 (MEL 2262570); Victoria: Eastern Highlands: Montrose, Austroflora Nursery, I.G. Stone 14411, 15 Sep 1977 (MEL 2219455).

Notes: Trematodon longicollis (Fig. 1), the type species of the genus, has been reported from Europe, North, Central and South America, Asia, Africa, India, Malesia, Papua New Guinea, Pacific Islands and Australia. It is a gregarious species of damp and disturbed soils, of exposed banks and soil over rock. The species, as presently circumscribed, is morphologically plastic (Bartram 1939; Gangulee 1987; Noguchi 1987; Eddy 1988; Cao \& Gao 1988; Crum 1994; Iwatsuki \& Suzuki 2006; Zander 2007) with some 36 taxa included as synonyms (www. tropicos.org accessed 21 Sep 2017).

Three Australian species, T. baileyi, T. brachyphyllus and T. longescens, previously considered as endemic (Streimann \& Klazenga 2002), are morphologically very similar to T. longicollis and have not been critically appraised since their original description. Type specimens (borrowed from $\mathrm{H}-\mathrm{BR}$ ) have been examined and illustrated for the first time. Over 100 unidentified Trematodon collections, mostly made by Ilma Stone, have been examined from Australian herbaria (NSW, MEL, BRI, HO), together with specimens previously identified as T. baileyi, T. brachyphyllus or T. longescens. Types of some synonyms of T. longicollis from other countries and held in NSW have also been examined: T. acutus (Isotype), T. pauciflorus Müll. Hal. (Isotype), and T. drepanellus Besch. (Syntype).

Only limited detail is given in the protologue of T. longicollis. The precise collection locality and location of the type is uncertain. The TROPICOS database indicates Michaux as the collector and locality as 'Eastern North America: in arenosis Carolinae. W.R. Buck (pers. comm.) suggests that a potential type may be found in the Michaux herbarium in Paris (PC). The British Natural History Museum database (http://www.gbif.org/ occurrence/1057030199] accessed 8 April 2015) includes reference to a lectotype specimen of T. longicollis Michaux. This specimen at BM of T. drepanellus Besch. id from Japan (Makkoda Urbain Jean Faurie 12716 $7^{\text {th }}$ June $1894 \mathrm{ex} \mathrm{Hb}$. E. Bescherelle), (BM-000964854) and was later identified as T. longicollis $21^{\text {st }}$ December 1987 by T. Cao and accepted as a lectotype.

Trematodon longicollis has been well illustrated for eastern North America, the type region, in Crum \& Anderson (1981) and Zander (2007). The capsule neck is described and drawn as appearing shorter when moist and longer when dry. The wide range of variation found in capsules, seta length and leaves in Chinese collections was illustrated by Cao \& Gao (1988), who concluded that seta length, leaf size and shape, and whether or not the leaf subula arises abruptly or gradually from the sheathing base, were all unreliable identification features. They found the most reliable characters were the ratio of capsule neck to urn length and the costa not occupying the full subula width. Indian species (Kumar 1985: 15 Plate III; Gangulee 1987) appear to have relatively longer necks and leaves with longer subulae.

In his key to species of Trematodon Brotherus (1924: 176) grouped together T. baileyi (as braileyi, sic), T. longicollis, T. ceylonensis Müll. Hal., T. conformis Mitt., T. callipes Müll. Hal., T. novae-hannoverae Müll. Hal., T. victoriae Müll. Hal., T. flexifolius Müll. Hal., and T. schroteri Broth. Most of these taxa have subsequently been included in the synonymy of T. longicollis as it is now circumscribed. These species share the following features: a well-developed peristome; cucullate calyptra; capsule length more than double the urn length; presence of a struma at the base of the capsule neck. Under various names these taxa are distributed widely in North America, India, Asia, Africa, New Caledonia and Australia.

\section{Re-evaluation of Trematodon baileyi Broth.}

Trematodon baileyi Broth., Öfvers. Förh. Finska Vetensk.-Soc. 33: 91-92. 1891.

Type citation: Queensland, Mulgrave River [Bellenden Ker Range], F.M.Bailey, 1889. 


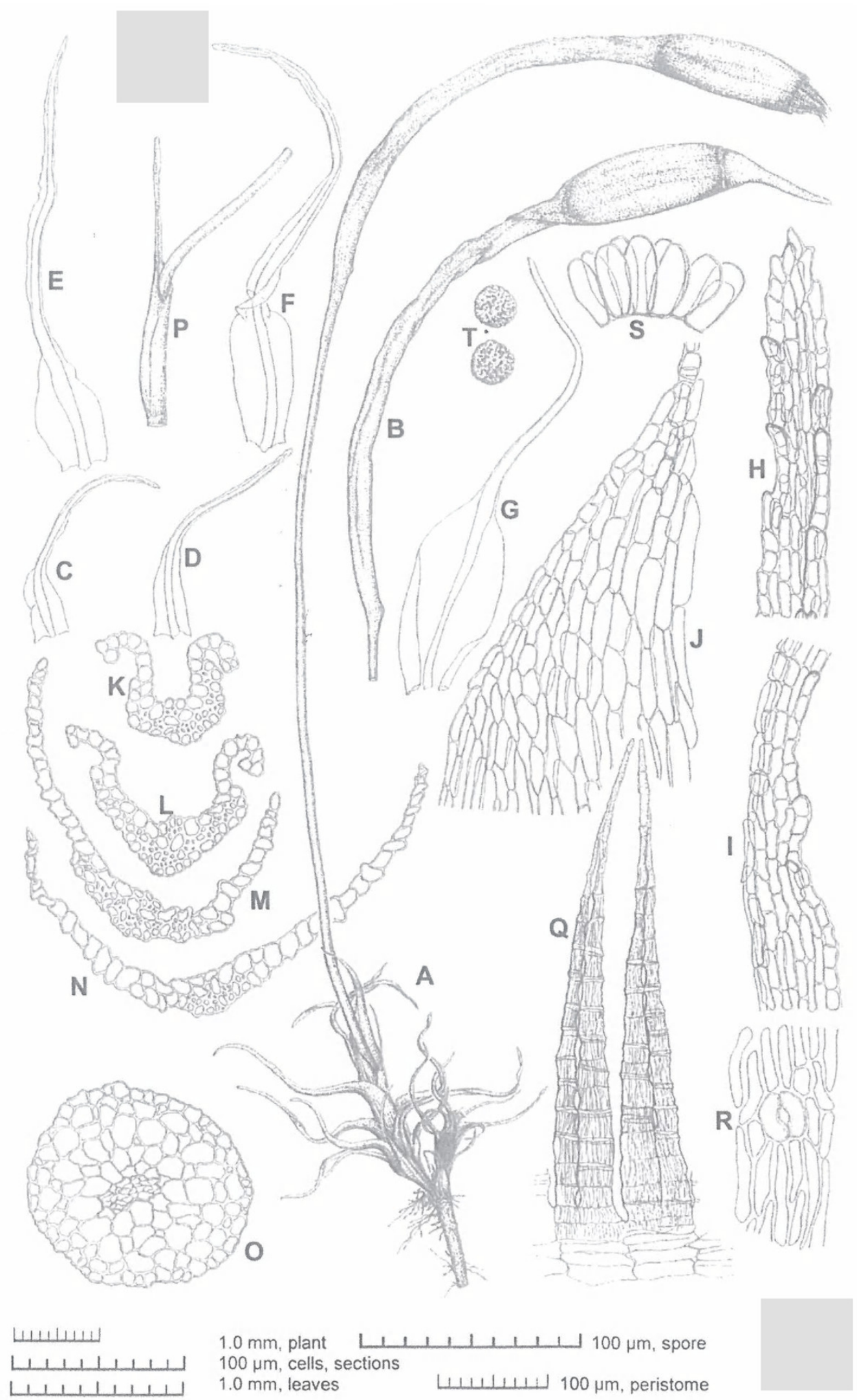

Figure 2. Trematodon baileyi. A. Fruiting plant; B. Mature capsule showing urn, apophysis and operculum; C-E. Stem leaves; F-G. Perichaetial leaves; H. Cells of leaf apex; I. Marginal cells at junction between leaf base and subula of stem leaf; J. Cells of shoulder region of upper stem leaf; K-L. Transverse section of leaf subula; M-N. Transverse section of sheathing leaf base; O. Stem section; P. Innermost perichaetial leaf sheathing base of seta; Q. Peristome teeth; R. Stomate from base of capsule urn; S. Annular cells; T. Spores.

Scale bars: $1.0 \mathrm{~mm}$ for plants and leaves; $100 \mu \mathrm{m}$ for cells, sections, peristome and spores.

Drawn from: Queensland: Mt. Bellenden Ker, F.M. Bailey Hb.652 (Isolectotype NSW) by R.D. Seppelt. 
Type: Bailey Hb.652 (lectotype here designated: H-BR 4270023; isolectotypes: BRI-AQ 722014, NSW 755030); Bailey Hb.670 (residual syntypes: H-BR 4270021, NSW, BRI).

Trematodon braileyi Broth., nom. inval. err. pro T. baileyi (orthogr. var.)

Autoicous. Plants loosely caespitose to densely gregarious, pale green. Stems short, $2.0-2.5 \mathrm{~mm}$ tall, erect, unbranched, rhizoids numerous, basal. Leaves $3.0-4.0 \mathrm{~mm}$ long, strongly crisped and flexuose when dry, flexuose-spreading to patent when moist, from a short sheathing base becoming rapidly linear-subulate, the subula channelled; margins revolute, bistratose in subula; apex acute and sparingly denticulate; lamina cells quadrate to short rectangular in subula, becoming elongate rectangular in sheathing base, thin-walled throughout; costa occupies up to 1/4-1/3 leaf base, not filling the subula.

Perigonia terminal on short shoots. Perichaetia terminal on main stem. Perichaetial leaves longer than stem leaves, 6.0-8.0 mm, erect, with a broad sheathing base and long flexuose subula. Setae slender, straight or somewhat flexuose, straw-coloured, smooth, 10-20 mm long. Capsule asymmetric, grey-brown to rusty-red, 4.0-7.0 mm long, curved, slender; urn 1.5-2.0 mm long, ovate-cylindric, neck long, curved, slender, $2-2.5 \times$ length of urn, strumose at base; stomata confined to neck; exothecial cells rectangular, 3-6×1, with thick lateral walls; annulus revoluble, of 3 layers of rectangular enlarged cells; operculum obliquely long-rostrate from a conical base, rostrum as long as urn; peristome single, reddish-purple, the tips pale, 350-420 $\mu \mathrm{m}$ long, teeth deeply cleft to near the base into slender filaments joined at tips, perforate below, vertically striolate, the tips papillose; calyptra cucullate. Spores rounded, small, yellow-brown, coarsely baculate-verrucose, $20-22 \mu \mathrm{m}$ in diameter.

Distribution: Known in Australia only from northeast Queensland.

Selected Australian collections named as T. baileyi: Queensland: North Kennedy: Wet Tropics, Mulgrave River, Mount Bellenden Ker, J.F. Shirley s.n. (BRI-AQ 0801247); near Cairns, C.J. Wild s.n., Aug 1890 (BRI-AQ 0801248; BRI-AQ 0860168); Mulgrave River, F.M. Bailey s.n. 1889 (MEL 32721).

Notes: The protologue of T. baileyi does not indicate specimen numbers but cites H-BR as the repository for types. Two specimens in H-BR named T. baileyi in Bailey's handwriting (Hb. 652, Hb. 670) are considered here as types. The collection location is given as Bellenden Ker Range.

In 1889, the Bellenden Ker Range expedition, led by A. Meston and including F.M. Bailey, established a base camp on the Mulgrave Plain. They climbed Mt. Bellenden Ker and returned to the Mulgrave River, collecting in the area from 17 July to 18 August 1889 (White 1950, Dowe \& Broughton 2007). The two locality names of Mulgrave River and Bellenden Ker Range have been used interchangeably on specimens. Watts \& Whitelegge (1902) give the locality as Bellenden Ker Range, Mulgrave River.

The specimen selected here as the lectotype for T. Bailey ( $\mathrm{Hb}$ 652) in $\mathrm{H}$-BR contains many plants, with capsules ranging in development from young to fully mature and is fully illustrated here (Fig. 2). The other specimen in $\mathrm{H}-\mathrm{BR}$ (Bailey $\mathrm{Hb} 670$ ) is then a residual syntype, with duplicates in BRI and NSW. A further specimen from the Mulgrave River (Bailey Hb 7 in NSW 299417 ex MEL) bears an annotation "T. baileyi type" and while it may have come from the same locality (Mulgrave River), the few plants present are poor and we thus exclude it as a type.

Trematodon baileyi, thought to have been an Australian endemic, has also been reported from New Caledonia (Brotherus 1909, 1911; Pursell \& Reese 1982). Whether this is in error for the more widespread T. longicollis needs further re-evaluation. No specimens labelled as T. baileyi from New Caledonia have so far been located in NOU, NICH or PC for comparison with Australian types.

In Australia, T. baileyi was known from a limited area of northeast Queensland, from Cairns and the Mulgrave River (Bailey 1890). It shares many critical features with T. longicollis (Table 1): peristome morphology; similar capsule neck to urn ratio; spore size; stem and perichaetial leaves with the same costal anatomy; the same relative width of the costa in the subula; bistratose margins in the subula; and leaf apex denticulate by projecting cell ends. Specimens identified as T. baileyi have a smaller plant size (stems $2.0-2.5 \mathrm{~mm}$ ) than T. longicollis (stems $5.0-10.0 \mathrm{~mm}$ ) and shorter setae $(10-20 \mathrm{~mm}$ against $8-30 \mathrm{~mm})$, but neither feature is reliable taxonomically (cf. Cao \& Gao 1988).

On the basis of our studies we consider T. baileyi to be synonymous with T. longicollis.

Using fresh material identified as T. baileyi from available taxonomic concepts at the time, a chromosome number $\mathrm{n}=14$ has been reported for the species (Ramsay 2011). 


\section{Re-evaluation of Trematodon longescens Müll. Hal.,}

Trematodon longescens Müll. Hal., Hedwigia 37: 109. 1898.

Type citation: Moreton, Beenleigh, Brisbane. F.M.Bailey

Type: Queensland: Moreton; Beenleigh, Brisbane, C.J. Wild, Aug 1887 (F.M. Bailey Hb. 440) (lectotype here designated: H-BR 4274008; isolectotype: BRI-AQ 0733989).

Epitype (here designated): New South Wales: Murwillumbah, T. Forsyth 656, x.1900 (NSW 754650)

Autoicous. Plants loosely tufted, pale green. Stems branched, 5-10 mm long. Leaves to $4.0 \mathrm{~mm}$ long, slightly curled when moist, flexuose-spreading from a broad pellucid subconvolute base narrowing abruptly to a long flexuose curved attenuate subula; apex weakly denticulate; margins unistratose in base, (uni-) bistratose in subula; lamina cells rounded, isodiametric to short-rectangular in subula, becoming broader, elongated and irregular in outline in sheathing base, thin-walled throughout; costa occupying 1/5-1/4 width of sheathing base, filling most of subula, ceasing shortly below apex.

Perigonia terminal on short shoots. Perichaetia terminal on stem. Perichaetial leaves large, $8.0-10.0 \mathrm{~mm}$ long including subula, long-subulate from a broad sheathing base. Setae slender, flexuose, yellow, $15-25 \mathrm{~mm}$ long. Capsule long-exserted, 5.0-7.0 mm long, urn oblong-cylindric, erect, $2.0-2.5 \mathrm{~mm}$ long, neck long, slender, strumose at base, 2-3× length of urn; stomata confined to neck; exothecial cells rectangular, 3-7 $\times 1$, with thick lateral walls; annulus of 2 or 3 layers of enlarged cells, revolute; operculum long-rostrate from a conical base, approximately as long as urn; peristome single, reddish, with a short membranous base, teeth long, split into two long slender filaments joined at tips, perforate below or deeply divided, vertically striolate, the pale tips papillose; calyptra cucullate. Spores brown, baculate-verrucose, $20-25 \mu \mathrm{m}$ in diameter.

Distribution: Known in Australia from Queensland and New South Wales.

Selected Australian collections named as T. longescens: Queensland: Moreton: ESE Warwick, Darling Downs, D.H. Norris 37817 (BRI 7339817; CBG 9211725); Cook: Wet Tropics: Rainforest Lodge, Kuranda R.G.Coveny 16763, 6 Aug 1998 (NSW-775075); Cook: Wet Tropics: Cairns, Barron River, W.W. Watts Q386, Aug 1913 (MEL 0029263A); New South Wales: Central Tablelands: Grose Vale, Blue Mountains, N. Klazenga 5947, 25 Sep 2001 (MEL 2931751); North Coast: Mt Boss State Forest, Waterfall Reserve, D.H Vitt \& H.P.Ramsay, Nov 1981 (CBG 921728); Tintenbar Road, $1 \mathrm{~m}$ (mile) from Ballina, W.W. Watts 362216 Sep 1899 (NSW 754702); Rous Hill Richmond River, W.W.Watts 4969, 4.vi.1901 (NSW 754713): South Coast: Cambewarra, W.Forsyth 995, Oct 1901 (NSW 7546840).

Table 1. Comparison of characters in the T. longicollis complex in Australia (T. baileyi, T. brachyphyllus, T. longescens) and of the New Caledonian T. longifolius.

\begin{tabular}{|l|l|l|l|l|l|}
\hline Attribute & T. longicollis & T. baileyi & T. brachyphyllus & T. longescens & T. longifolius \\
\hline Plants $(\mathrm{mm})$ & $2.5-6.0$ & $2.0-2.5$ & $1.5-2.0$ & $3.5-10.0$ & $2.0-3.0$ \\
\hline Sexuality & autoicous & autoicous & ? autoicous & autoicous & autoicous \\
\hline Stem Leaves $(\mathrm{mm})$ & $1.7-3.6$ & $3.0-4.0$ & $1.0-3.0$ & $1.5-3.5$ & $1.0-3.5$ \\
\hline Costa & not filling subula & not filling subula & not filling subula & not filling subula & not filling subula \\
\hline Leaf apex & denticulate & denticulate & denticulate & denticulate & denticulate \\
\hline Perichaetial leaves $(\mathrm{mm})$ & $5.0-8.0$ & $6.0-8.0$ & $2.5-3.5$ & $2.5-4.0$ & $4.0-6.0$ \\
\hline Setae $(\mathrm{mm})$ & $10.0-30.0$ & $10.0-20.0$ & $15.0-20.0$ & $15.0-25.0$ & $15.0-20.0$ \\
\hline Capsules & long cylindrical & long cylindrical & long cylindrical & long cylindrical & long cylindrical \\
\hline Capsule length $(\mathrm{mm})$ & $5.0-7.0$ & $4.0-7.0$ & $4.5-6.0$ & $5.0-7.0$ & $4.5-6.0$ \\
\hline Urn length $(\mathrm{mm})$ & $2.0-2.9$ & $2.0-2.5$ & $1.5-2.0$ & $2.0-2.5$ & $1.5-2.0$ \\
\hline Neck length $(\mathrm{mm})$ & $4.5-6.0$ & $4.0-7.0$ & $3.0-4.5$ & $4.0-7.5$ & $2.5-4.0$ \\
\hline Neck : Urn ratio & $2.0-3.0$ & $2.0-2.5$ & $2.0-2.5$ & $2.0-3.0$ & $1.5-2.0$ \\
\hline Struma & present & present & present & present & no data \\
\hline Peristome teeth & 16, bifid, perforate & 16, bifid, perforate & 16, bifid, perforate & 16, bifid, perforate & no data \\
\hline Peristome length $(\mu \mathrm{m})$ & $330-430$ & $350-420$ & $350-450$ & $250-300$ & no data \\
\hline Operculum & long rostrate & long rostrate & long rostrate & long rostrate & no data \\
\hline Spores $(\mu \mathrm{m})$ & $20-25$ & $20-22$ & $15-20$ & $20-25$ & no data \\
\hline
\end{tabular}




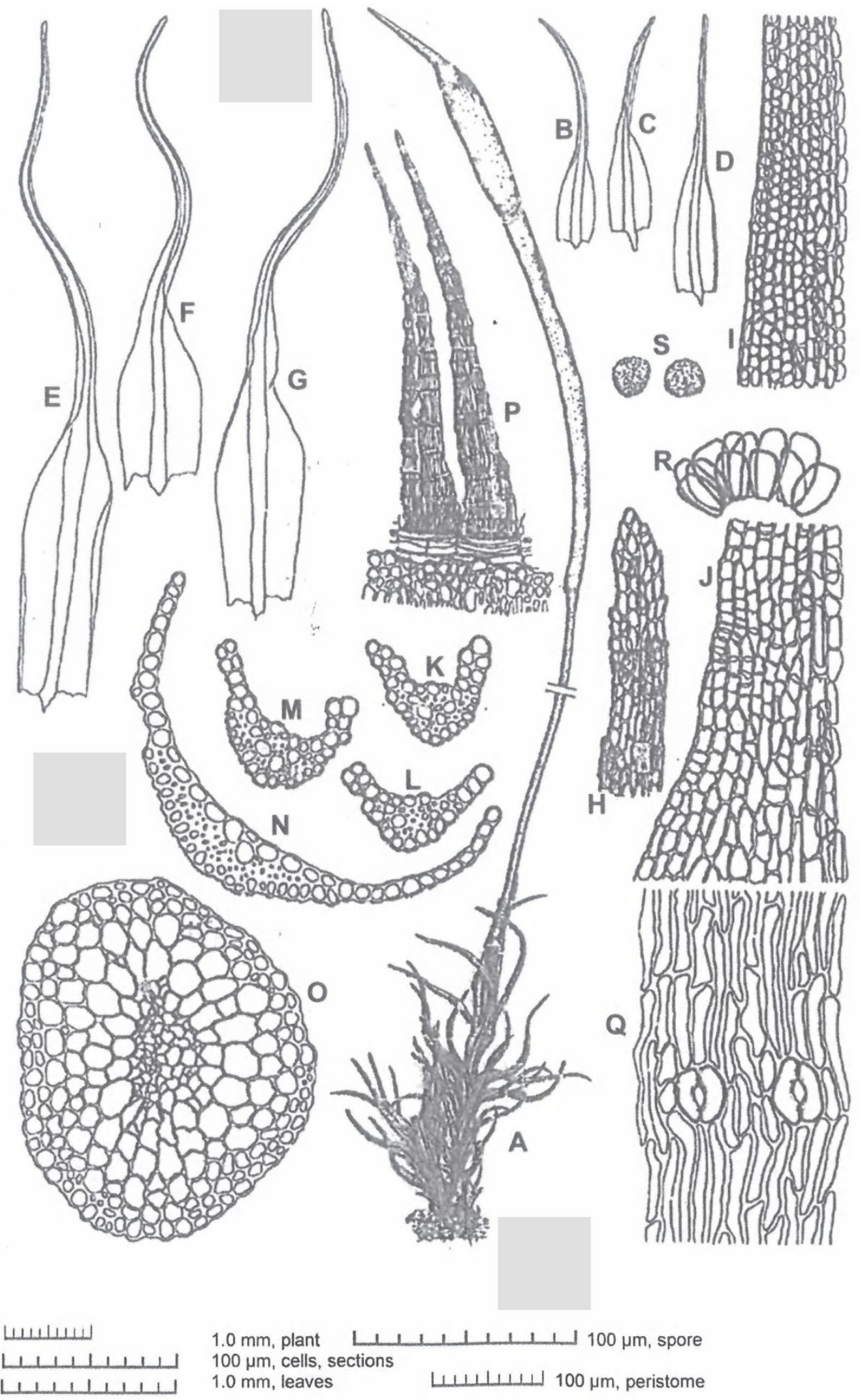

Figure 3. Trematodon longescens. A. Fruiting plant with seta foreshortened. B-D. Stem leaves; E-G. Perichaetial leaves; H. Cells of leaf apex; I. Marginal cells of leaf subula; J. Cells of leaf shoulder region; K-M. Transverse sections of leaf subula; N. Transverse section of sheathing leaf base; O. Stem section; P. Peristome teeth; Q. Stomate at base of urn; R. Annular cells; S. Spores.

Scale bars: $1.0 \mathrm{~mm}$ for plants and leaves; $100 \mu \mathrm{m}$ for cells, sections, peristome and spores.

Drawn from: NSW: Murwillumbah., T. Forsyth 656, ix.1900 (NSW-754640) [Epitype-See under T. longescens in text.] by R.D. Seppelt. 
Notes: Three different collections are cited in the protologue: New South Wales, Sydney, Domina Kayser in herb. Geheeb, 1872; Richmond River, Capt. Stackhouse, in herb. Melbourne, 1881; Queensland, Brisbane River, F.M.Bailey, in Herbarium Brotherus, 1888.

The Domina Kayser collection from Sydney, presumably originally located in Hb. Geheeb in Berlin, has not been located and it may have been lost in the destruction of the Berlin Herbarium during the Second World War. Some Geheeb specimens were sent to Jena (JE), but the T. longescens specimen was not amongst them (F. Mueller, pers. comm.). No duplicates have been located in JE, NSW or MEL.

A possible duplicate Stackhouse specimen from Richmond River, although labelled as T. longescens (MEL 2278264), now contains only plants of Camptochaete excavata (Taylor) A.Jaeger and no material of Trematodon.

The remaining specimen cited in the protologue is from Brisbane, C.J. Wild (F.M.Bailey Hb. 440), 1888 (H-BR 4274008) and is chosen here as the lectotype. However, the collection is small and poor with only two stems bearing capsules, hence none was used for illustration. The isolectotype consists of only a few leafy plants and does not have capsules.

In the absence of suitable material for illustration or of identifiable specimens relevant to the taxon mentioned in the protologue, we have selected an epitype to serve as an interpretive type that can critically identify and be applied to the taxon [ICN articles 9.7,9.18]. As the sporophyte is of critical significance for the description and identification of species in Trematodon, T. Forsyth 656, ix.1900. (NSW 754640) is here designated as an epitype, and used for illustration (Figure 3). The epitype specimen matches the lectotype, and is from an area of northern New South Wales, a locality listed in the protologue and not too far from Brisbane, the site of the lectotype. There are several large duplicate collections of Forsyth 656 (in NSW), each of which includes large numbers of fertile specimens.

Trematodon longescens and T. longicollis express a similar range of variation in their sporophytes. In T. longescens, the capsule neck appears to be consistently longer and both stem and perichaetial leaves differ in the relative length and curvature of the subula (Table 1). However, population variability suggests that these differences may be due to environmental influences and we do not consider them significant in species differentiation.

From our studies of early and recent collections we conclude that T. longescens should be reduced to synonymy of T. longicollis.

A chromosome number $n=15(14+m)$ was obtained from material identified as $T$. longescens from available taxonomic literature at the time (Ramsay 2011).

\section{What is Trematodon brachyphyllus?}

Trematodon brachyphyllus Müll. Hal., Hedwigia 37: 109. 1898. "Australia tropica”, Queensland, sin. loco. F.M. Bailey in H-BR.

Type citation: "Australia tropica", sin loco, F.M. Bailey

Type: F.M.Bailey Hb.233 (holo: H-BR 4270022!).

Trematodon trachyphyllus Müll. Hal. ex Paris, nom. inval. err. pro. (orthogr.).

?Autoicous. Plants $2-5 \mathrm{~mm}$ tall. Stems simple or branched; in section with a central strand and poorly defined outer cortical row of cells. Leaves $1.0-3.0 \mathrm{~mm}$ long, erect-spreading from an ovate-oblong sheathing base contracting to a broad flexuose channelled subula 1-3 times length of base; apex denticulate; margins unistratose in sheathing base, bi- or occasionally tri-stratose in subula with occasional bistratose patches in subula lamina; lamina cells in subula and upper part of leaf base irregular in outline, rhomboid to rectangular to irregularly hexagonal, \pm equidimensional to $c .3 \times 1$, becoming elongate and $c .5-10 \times 1$ in leaf base, thinwalled throughout. Costa narrow throughout, occupying $c .1 / 3$ width of subula, subpercurrent, in section with well-defined adaxial and abaxial substereid bands.

Perigonia not seen. Perichaetia terminal on stem. Perichaetial leaves larger than stem leaves, subulate from an ovate sheathing base. Setae slender, flexuose, erect, reddish-yellow, 8-9 mm long. Capsule narrow, cylindrical, 4.5-6.0 mm long, urn c. 1.5-2.0 mm long; neck at least $2 \times$ length of urn, strumose at base; stomata confined to neck; exothecial cells rectangular, 3-6×1, with thickened lateral walls; annulus revoluble, of 2 or 3 layers of rectangular enlarged cells; operculum obliquely long-rostrate from a conical base, about as long as urn; peristome single, $350-450 \mu \mathrm{m}$ long, teeth narrow lanceolate, deeply divided and perforate. Spores coarsely baculate-verrucose, $15-20 \mu \mathrm{m}$ in diameter. 


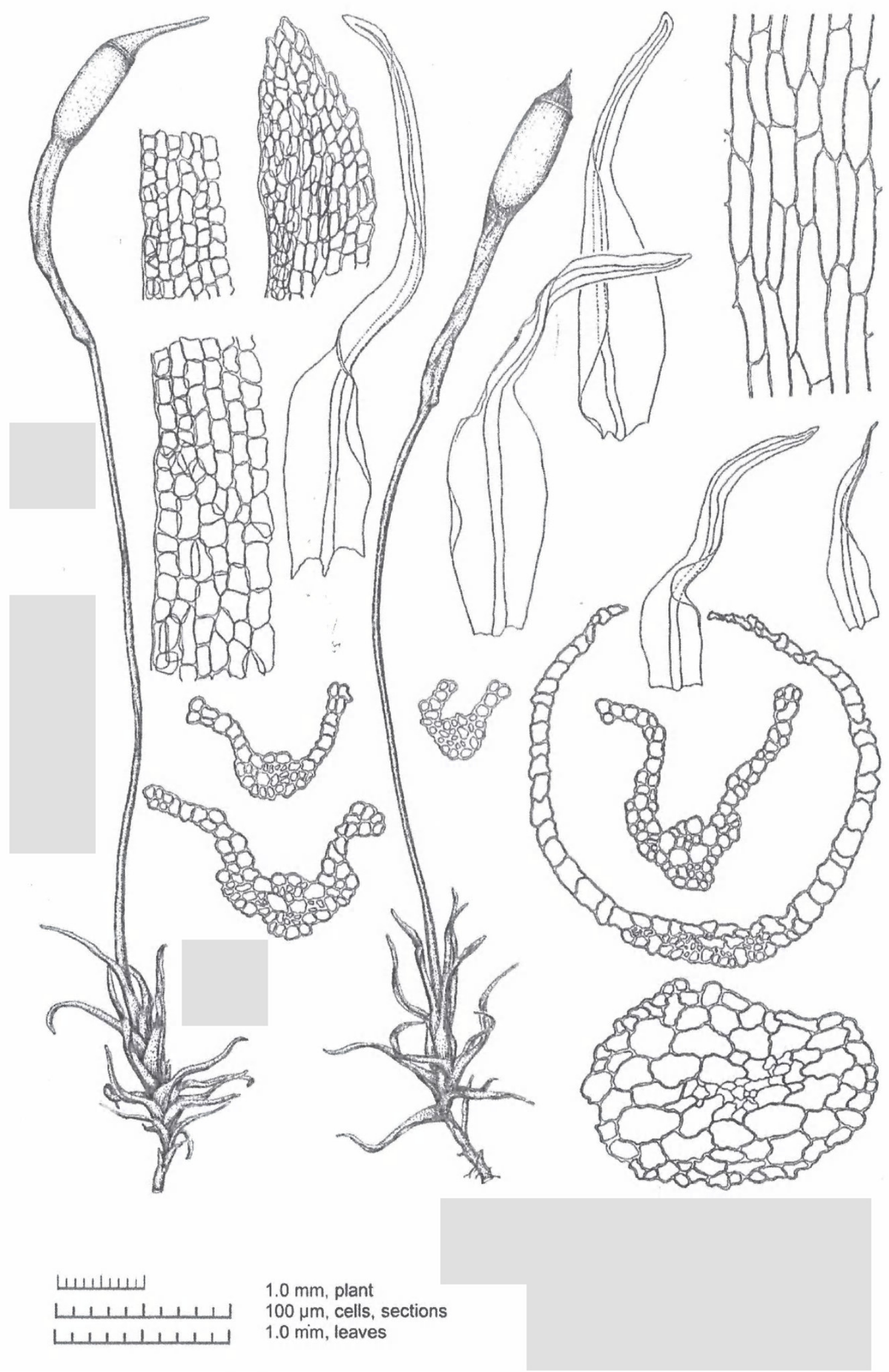

Figure 4. Trematodon brachyphyllus. Figure 4: A-B. Fruiting plants; C-D. Lower stem leaves; E-G. Perichaetial leaves; H. Cells leaf apex; I. Cells of subula margin; J. Cells of upper part of sheathing leaf base; K. Cells of lower leaf base; L-O Transverse sections of leaf subula; P. Transverse section of leaf base; Q. Stem section.

Drawn from: Queensland: Tropical Queensland sin. loc. F.M.Bailey Hb.233, Holotype: (H-BR-270022) by R.D. Seppelt. 


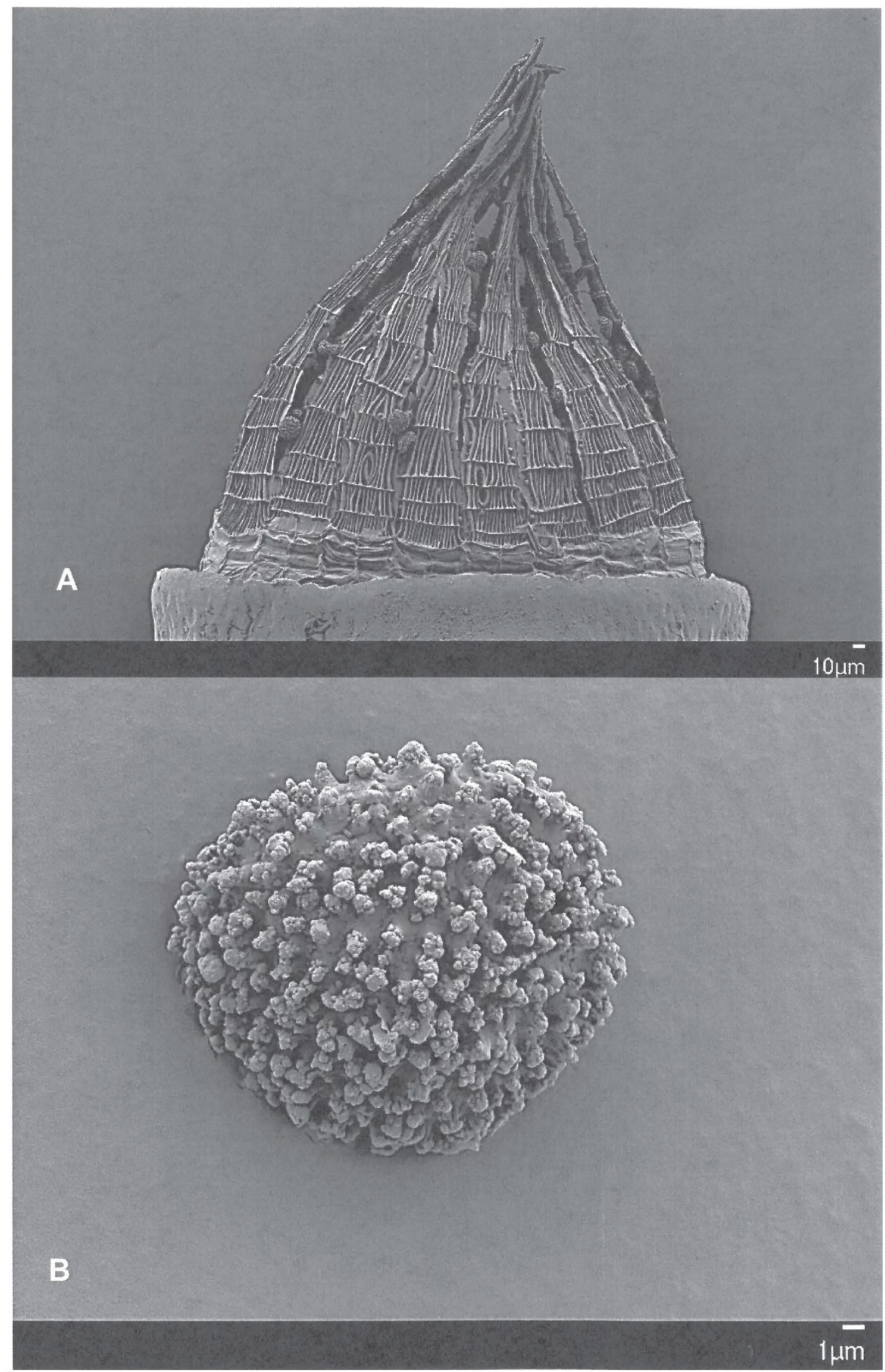

Figure 5. Trematodon brachyphyllus. A - SEM of spore, B - SEM of peristome. Scale Bars: $1.0 \mathrm{~mm}$ for plants and leaves; $100 \mu \mathrm{m}$ for cells, sections and spores. From: -Queensland: sin. loc. FM Bailey Hb.233. Holotype (HBR-4270022) by R.D. Seppelt. 
Distribution: Known in Australia only from the type specimen from an unknown location in Queensland.

Notes: The holotype is the only specimen of T. brachyphyllus we have located. The Bailey Herbarium number indicates it probably came from the Moreton district near Brisbane, in south eastern Queensland.

According to the protologue, T. brachyphyllus is characterised by an obtuse leaf apex and small spores, although no indication of spore diameter was given. Measurements we have made of the type specimen indicate a spore diameter range of 15-20 $\mu \mathrm{m}$, placing it within the lower range of spore diameter reported for T. longicollis. The apex of both stem and perichaetial leaves is bluntly acute to obtuse. Peristome teeth are 350-450 $\mu \mathrm{m}$ long and similar in length and ornamentation to those of T. longicollis (Table 1).

Both T. brachyphyllus and T. longicollis share similar leaf anatomy, having a narrow costa in the subula, bi(tri)-stratose subula margins and the unistratose margin of the leaf base. The capsule neck to urn length ratio is almost identical in specimens we have examined that have been labelled as T. baileyi or T. longescens, both of which we have here reduced to synonymy of T. longicollis.

The holotype specimen is very similar morphologically to a specimen of T. longicollis we have examined from Japan (Fig. 1) and to published illustrations of T. longicollis, e.g. from the type region of eastern North America (Crum \& Anderson 1981: 163, Fig. 67H-L; Zander 2007: 436). From our studies we consider T. brachyphyllus to be synonymous with $T$. longicollis.

Two Australian collections we have examined were labelled as T. brachyphyllus but are not referrable to the species and have been excluded. One, from Mt. Perry, Queensland, Bailey Hb.231 leg. J.Keys (BRI), is listed in Watts \& Whitelegge (1902) and also in AUSMOSS (accessed February 2014). It includes a mixture of species with a few plants of Trematodon, only four of which have sporophytes. We regard this specimen as unequivocally belonging to T. suberectus. The second collection (Northern Territory, Palm Valley, I.G. Stone (MEL 1038763) is a mixed gathering of Fissidens and a dicranoid moss lacking capsules which we are unable to determine to genus with certainty.

From our studies of early and recent collections we conclude that $T$. brachyphyllus should be reduced to synonymy of T. longicollis.

\section{Trematodon longifolius from New Caledonia}

Trematodon longifolius Broth. \& Paris in Broth., Öfvers. Förh. Finska Vetensk.-Soc. 51: A(17): 1. 1909 [initially identified as T. novae-caledoniae Müll.Hal. nom. nud.].

Type citation: Route de Bouvrail \& Kousilon, Nemeara. Le Rat 1905.

Type: New Caledonia: route de Bouvrail \& Kousilon, Nemeara Le Rat s.n., July 1905. (holo: H-BR 4270014; iso: herb. Thériot PC 0101581).

Autoicous. Plants small, gregarious, loosely tufted, glossy. Stems short, erect, 2.0-3.0 mm tall, unbranched, in section with a central strand; rhizoids basal. Leaves crispate when dry, flexuose patent when moist; stem leaves to $c .3 .5 \mathrm{~mm}$ long, linear-subulate from an oblong base, margins erect; apex obtuse, minutely denticulate; lamina cells of subula and upper lamina small, subquadrate to short rectangular, cells of base irregularly rectangular to rhomboid-hexagonal, thin walled, non-porose, narrower towards margins; margins unistratose in base, bistratose in subula; costa ending below the apex, occupying $c .1 / 6$ of lamina at base, almost but not filling the subula.

Perichaetia terminal on stem. Perichaetial leaves large, 4.0-6.0 $\mathrm{mm}$ including subula, contorted when dry, base sheathing, $1.0 \mathrm{~mm}$ wide, $1.5 \mathrm{~mm}$ long, subula $4.0-4.5 \mathrm{~mm}$ long. Setae $15-20 \mathrm{~mm}$ long, slender, flexuose. Calyptra pale, cucullate. Capsules upright to somewhat curved; urn $1.5-2.0 \mathrm{~mm}$ long; neck $2.5-4.0 \mathrm{~mm}$ long, strumose, twisted; operculum rostrate, same length as urn. As the plants have immature capsules no comparative data on exothecial cells, annulus, peristome or spores is available.

Notes: The type of T. longifolius has been compared to Australian specimens identified as T. longescens and T. baileyi. When described, T. longifolius was considered to be close to T. acuta (= T. acutus) which had much longer smooth leaves and which has subsequently been placed into synonymy with T. longicollis.

In his key to Trematodon, Brotherus (1924: 172-173) omitted to list T. longifolius, although he had earlier described the species from New Caledonia (Brotherus 1909, 1911). 

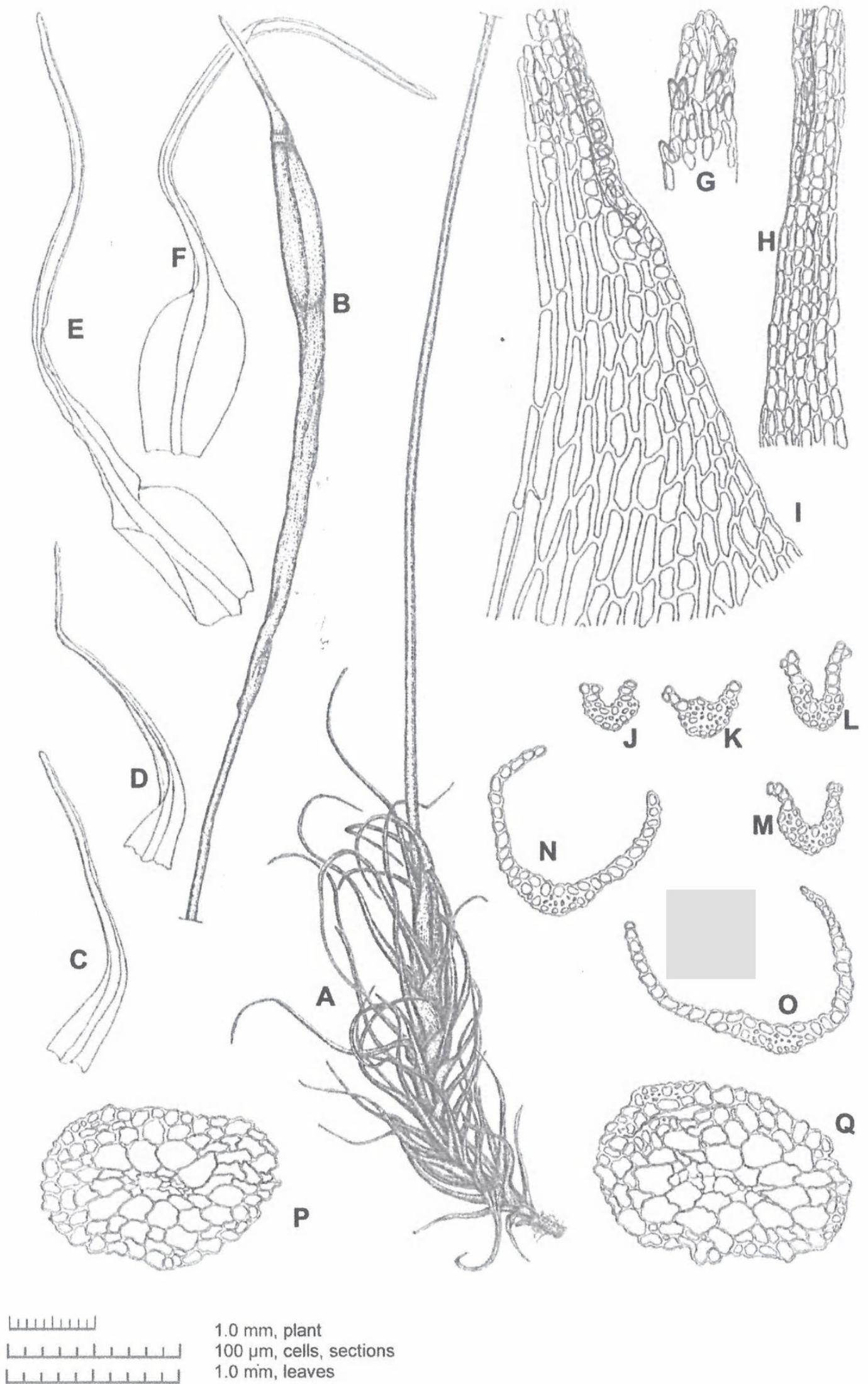

Figure 6. Trematodon longifolius. A. Fruiting plant plus part of seta; B. Upper seta and immature capsule; C-D. Stem leaves; E-F. Perichaetial leaves; G. Cells of leaf apex; H. Marginal cells of leaf subula; I. Cells of leaf shoulder region; J-M. Transverse section of leaf subula; N-O. Transverse sections of basal part of leaf; P-Q. Stem sections. Scale Bars: $1.0 \mathrm{~mm}$ for plants and leaves; $100 \mu \mathrm{m}$ for cells, sections and spores.

Drawn from: New Caledonia: Nemeara, Le Rat vii.1905. Holotype (HBR-4270014) by R.D. Seppelt. 
In addition to T. longifolius, several other species have been reported in the New Caledonian flora. Miller et al. (1978) included T. longicollis and Pursell \& Reese (1982) listed, in addition, T. baileyi, T. novae-hannoverae Müll. Hal., T. paucifolius Müll. Hal., and two nomina nuda, T. ludovicae Broth. \& Paris in Broth., and T. novaecaledoniae Müll. Hal.

Tixier (1986) placed T. ludovicae and T. novae-caledoniae into synonymy of the Australian T. bayleyi (sic.). Tixier based his conclusions on the leaves of the three species being identical, with similar seta length of $1.0 \mathrm{~cm}$ $(1.5 \mathrm{~cm}$ for T. baileyi) and similarity of the peristome and annulus. No mention was made of the capsule neck to urn ratio. Tixier also placed T. paucifolius and T. longifolius into synonymy with $T$. longicollis on the basis of comparable leaf and setae length, again with no reference to capsule neck to urn ratio, while specimens from New Caledonia, identified as T. novae-hannoverae, were considered to be referrable to Microdus glaucus (Besch.) Paris. There are no illustrations to enable comparison and we have not been able to re-examine New Caledonian collections.

Thouvenot \& Bardat (2010), citing Tixier (1986), accepted the placement of T. novae-caledoniae as a synonym of T. bayleyi (sic.). They noted that Norris \& Koponen (1990), in their studies of the mosses of the Huon Peninsula, Papua New Guinea, accepted T. paucifolius as a synonym of T. longicollis. Thouvenot \& Bardat (2010) however, retained T. ludovicae, T. longifolius and T. novae-hannoverae as endemic species, despite Tixier (1986) placing these into synonymy. They provided no explanation for these different interpretations. Updated species information for New Caledonia in Thouvenot \& Bardat (2013) did not include a re-evaluation of Trematodon.

We have been unable to obtain for comparative study any New Caledonian specimens determined as T. baileyi from PC or NOU. We are thus unable to make any definitive assessment but have made the presumption that any specimens so identified would fit within the broader concept of T. longicollis.

The New Caledonian type of T. longifolius (initially named as T. novaecaledoniae) has been studied and is illustrated here (Fig. 6). The plants are very similar morphologically to the Australian T. longescens (Fig. 3). We consider that the smaller stem diameter, smaller cell size in the subula, and slightly longer cells in the leaf base result from plant age or environmental variations. Unfortunately, as the capsules are immature, most useful data for comparison is thus not available. However, we agree with the conclusions of Tixier (1986) that T. longifolius is synonymous with $T$. longicollis.

\section{Costal anatomy in leaves of Trematodon species}

During our revision of Trematodon in Australia we realised that costal anatomy, a character not discussed in literature and rarely included in illustrations, could be of taxonomic importance in distinguishing certain species and is particularly valuable in sorting out the conundrum of the synonymy of $T$. longicollis. The relative width of the costa in the subula is mentioned as significant between species, but the anatomy in transverse section of the costa, especially in the leaf base, has been illustrated only rarely and not discussed. It is essential to make a series of sections from leaf base to apex to determine the costal anatomy and the extent to which the costa fills the subula. The general leaf anatomy of stem leaves and perichaetial leaves is quite similar.

Illustrations of leaf base sections are found in Noguchi (1987:137 Fig. $52 \mathrm{c1}, \mathrm{c} 2)$ for T. longicollis but not in Cao \& Gao (1988), Crum \& Anderson (1981), or Gangulee (1987). Iwatsuki \& Suzuki (2006) provide illustrations of leaf sections for T. ambiguus (Hedw.) Hornsch. and T. asanoi Tuzibe but none for T. longicollis, although the species occurs in Japan and is compared with the other two species cited in the paper.

The illustrations of leaf sections for six different Trematodon species by Magill (1981: 113, Fig. 29; 116, Fig. 30) demonstrate some quite distinct differences between species in the costal anatomy of leaf bases. The section for T. longicollis is identified, by the bistratose margin and presence of guide cells in the costa, as being apparently from the proximal part of the leaf subula just above the sheathing leaf base.

Although not specified in publications, the drawings of sections of the leaf base in T. longicollis can be distinguished from sections of the subula. In Figures 1-6 the origin of the leaf sectioned as stem or perichaetial leaf is not usually specified but these leaves are similar in structure. To make comparisons easier, we have arranged the transverse leaf sections for each of the species examined (see Figs 1-6) into a composite (Fig. 7). Key features to note are summarised below. 


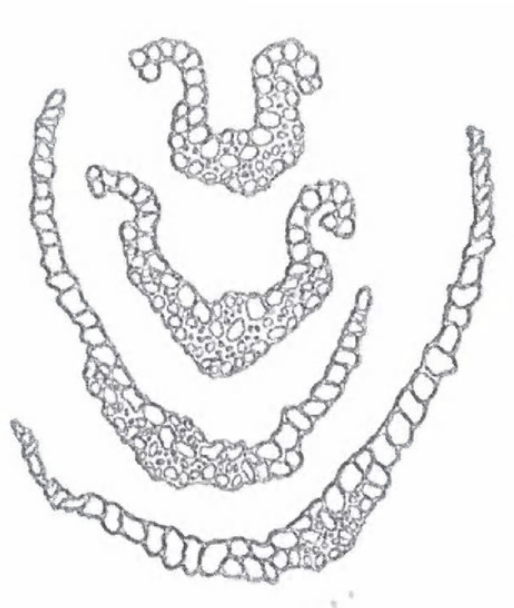

C Trematodon baileyi

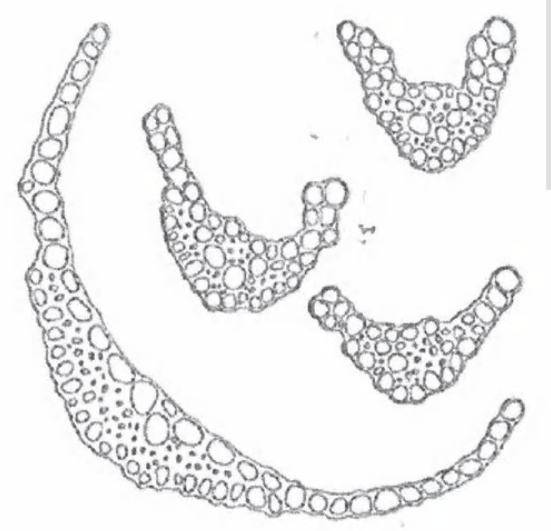

B Trematodon longescens

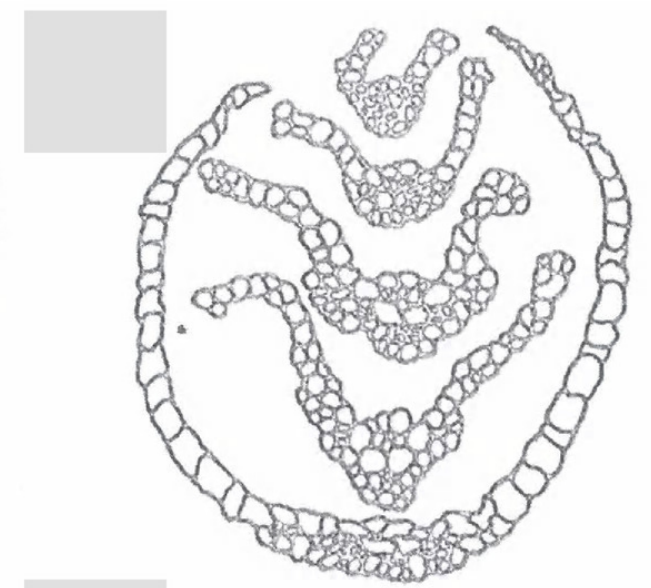

D Trematodon brachyphyllus

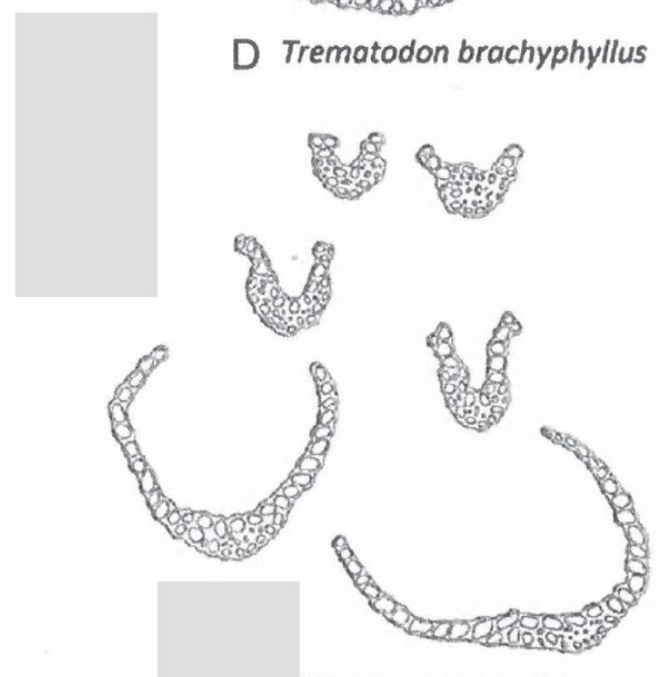

E Trematodon longifolius

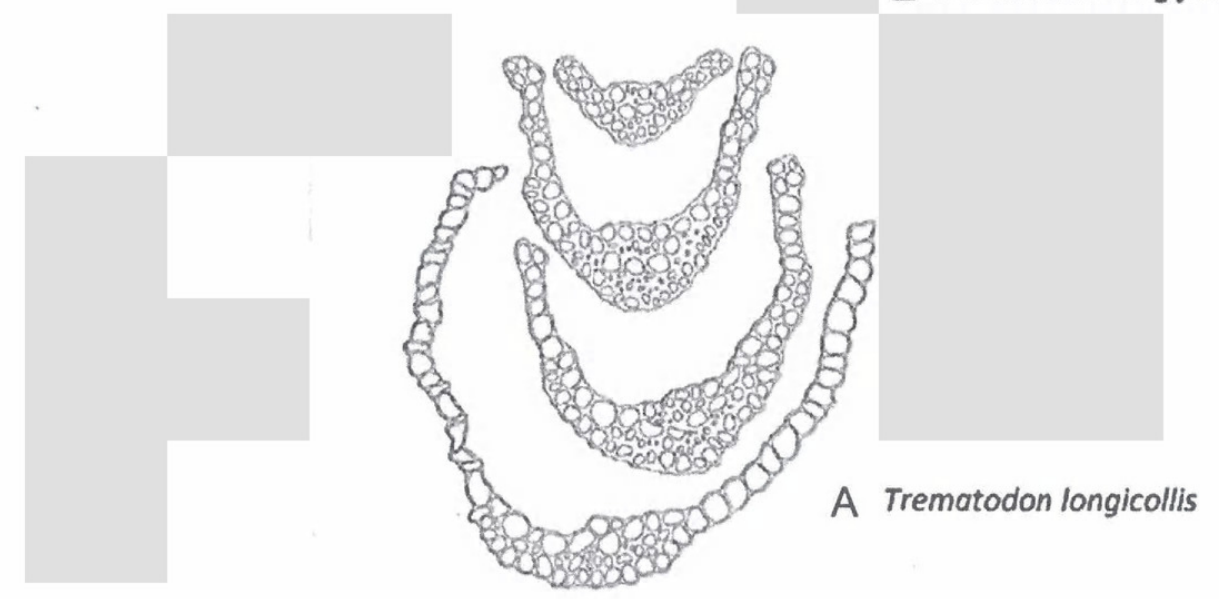

Figure 7. Comparison of transverse sections of leaves in Trematodon longicollis and its synonyms as determined here. A. Trematodon longicollis - A1 base of leaf, from Noguchi (1987, figure 52 e); A2 series of sections from base to subula, from figure 1 here; A3 from Magill (1982, figure 30) section near junction between base and subula (note bistratose margin and presence of guide cells). B. Trematodon longescens - showing sections from base and subula from figure 3; C. Trematodon baileyi - showing sections from base and subula from figure 2; D. Trematodon brachyphyllus - showing sections from base and subula from figure 4; E. Trematodon longifolius - showing sections from base and subula from figure 6. 
1. In sections of the leaf base, the marginal cells are usually unistratose, but are bistratose in the subula.

2. In the leaf base, the costa occupies a smaller part of the leaf section but up to about half of the subula. Note that in some other species it fills or nearly fills the subula.

3. In the leaf costa, guide cells (deuters) are present only in sections of the subula and do not occur in the basal section. This may differ in some other species.

4. Apparent differences in clarity of cells are due to the age of the specimens sectioned, some of which were collected in the 1890s.

5. Leaf sections of T. longicollis (Noguchi (1987) show that in the mid region of the leaf base, the costa has a distinct single layer of large cells adaxially and a layer of smaller cells abaxially, respectively forming upper and lower epidermal layers. Between these layers the cells are small and thick-walled sclereids, uniform in size, and several layers deep. Our study of T. longicollis, also based on Japanese material, (see Fig. 1) is similar, as is that of T. longescens in Australia (Fig. 3).

Although there is similarity between the anatomy of stem leaves and perichaetial leaves the perichaetial leaves are larger (Table 1, Figs 1-6). When making a comparison, consideration needs to be given to the fact that sections in different species have been taken at different parts of the leaf while the size of leaves is variable between and within species. In each species a range of sections from base to subula is available and the similarities are clear (Fig. 7).

Data supporting our conclusions relating to Australian species of the Trematodon longicollis complex include:

1. Overall morphological similarity to T. longicollis (Noguchi 1987, Fig. 51e1,e2) including features rarely illustrated in other studies.

2. Conformity to the summary of diagnostic features for Trematodon species, based on sporophyte characters only (Iwatsuki \& Suzuki 2006: 263, Table 1). For T. longicollis these are: setae 15-30 mm; capsules curved, urn 2.0-2.9 mm, neck (apophysis) $4.5-8.9 \mathrm{~mm}$; peristome teeth $330-430 \mu \mathrm{m}$ long, forked or perforate; spores $20-25 \mu \mathrm{m}$ in diameter.

3. The wide range of variation in both gametophyte and sporophyte characters, as shown by Cao \& Gao (1988, Table 1, Figs 1-3) in their review of Trematodon in China.

4. Similarity to the leaf and capsule characters shown by Eddy (1988: 107, Fig. 98) for Malaysian populations of T. longicollis.

5. Close similarity to South African material of T. longicollis, as described and illustrated by Magill (1982: 115-117, Figs 21-29, 30).

6. Leaf lamina and costal anatomy reveals similarity between the species examined here and T. longicollis, but differs between this and other species.

\section{Concluding Remarks}

Our studies and conclusions regarding Trematodon in Australia are based on detailed morphological and anatomical investigations, including examination of types where available and comparison with descriptions and illustrations of $T$. longicollis from other regions of the world. Although several attempts have been made to obtain molecular information from Australian specimens, these studies so far have not provided useable evidence for comparison. Most Australian herbarium collections are very old and good living material with fully mature sporophytes has been difficult to obtain.

Preliminary molecular data are available for Trematodon longicollis in North America (La Farge et al. 2002; Shaw et al. 2005; Cox et al. 2010; Fiz-Palacios et al. 2011) through GenBank. None has been obtained as part of a broader taxonomic study of the genus Trematodon but as part of a broad-scale evolutionary study of the family Dicranaceae. Each investigation concentrated on a different origin of the DNA (chloroplast, ribosomal, nuclear, mitochondrial) and the results are therefore not directly comparable. In total, the genes for which any information is available are: cpDNA: $r p s 4$, $\operatorname{trnL}$ and $\operatorname{trnL}-\operatorname{trnF}$ spacer; rRNA: $t R N A-S e r$; nucDNA: Nuc26S; mtDNA: nad5. Of these, $r p s 4$ and $\operatorname{trnL}-\mathrm{F}$, would be useful at species level. However the spacer region tends to be more informative at species level, but for any analysis a series of exemplars will be necessary. 
Any molecular study undertaken on such a diverse and variable taxon as T. longicollis needs to compare the same genetic markers in material collected from a range of localities, both locally and from the broader geographical compass. No such study has been undertaken for any region of the world or for any of the wide range of taxa now placed in synonymy with T. longicollis. Australian chromosome studies (Ramsay 2011) of the two species named as T. baileyi and T. longescens, record the numbers $n=14,15(14+\mathrm{m})$. As these two species are now included in synonymy, the chromosome data applies to the single species T. longicollis. Cytological evidence from North America (Fritsch 1991) indicates the presence of polyploidy, suggesting that a detailed multi-region morphological, cytological, molecular and phylogenetic study may help elucidate the interrelationships within the T. longicollis complex geographically.

A range of character variation in both gametophyte and sporophyte, including plant size, cells dimensions, relative length of the leaf subula to the sheathing base, degree of flexion of the subula, seta length, ratio of capsule neck to urn length, is found both within and between Australian populations that have previously been determined as T. baileyi, T. longescens and T. brachyphyllus (Table 1). While particular characters vary, all the taxa share the following: capsules with an elongated neck (apophysis) that is usually strumose at the base and consistently having the neck greater than or equal to two times the urn length; revoluble annulus; reddish peristome teeth that are relatively long $(350-450 \mu \mathrm{m})$, mostly perforate or bifid but usually joined at the tip, with pale and lightly papillose apices and the remainder of the peristome longitudinally striolate. All the taxa have stem and perichaetial leaves with a long flexuose subula $2-3 \times$ the length of the sheathing base; in section the costa occupies $c .1 / 3-1 / 2$ the subula width; the pattern of costal anatomy is also similar (Fig. 7); leaf margins are bistratose in the subula and unistratose in the leaf base; the leaf apex is weakly denticulate by projecting cell ends.

These characters are all shared with the type species for the genus, T. longicollis, itself a very variable species or species complex that is widespread geographically in both northern and southern hemispheres.

\section{Taxonomic implications for T. longicollis from Australia}

Trematodon longicollis Michx., Flora Boreali-Americana 2: 289. 1803.

=Trematodon baileyi Broth., Öfvers. Förh. Finska Vetensk.-Soc. 33: 91-92. 1891. syn. nov.

=Trematodon brachyphyllus Müll. Hal., Hedwigia 37: 109. 1898. syn. nov.

=Trematodon longescens Müll. Hal., Hedwigia 37: 109. 1898. syn. nov.

$=$ Trematodon longifolius Broth. \& Paris in Broth., Öfvers. Förh. Finska Vetensk.-Soc. 51A (17): 1. 1909.

[New Caledonia fide Tixier (1986).

\section{Acknowledgements}

We wish to thank Allan Fife, Allan Herbarium, Lincoln, New Zealand, for sharing information on species of Trematodon found in New Zealand. The directors of other herbaria (BRI, H-BR, HO, MEL, NSW) have provided access to specimens including types. Reference specimens of T. longicollis, from the Hattori Botanical Laboratory, Japan, were sent by the late Zennoske Iwatsuki for comparison with Australian collections. Suggestions for the location of possible types of T. longicollis were provided by William Buck, New York Herbarium. Photos of the type of T. longifolius and other information about the Trematodon collections at the Geheeb Herbarium obtained from Frank Mueller, Dresden were helpful. Colour photos of Trematodon longicollis (Fig. 8) were supplied by Andi Cairns. Rod Seppelt produced the original drawings of Trematodon in Figures 1 to 7 Our grateful thanks to all those who have helped. 


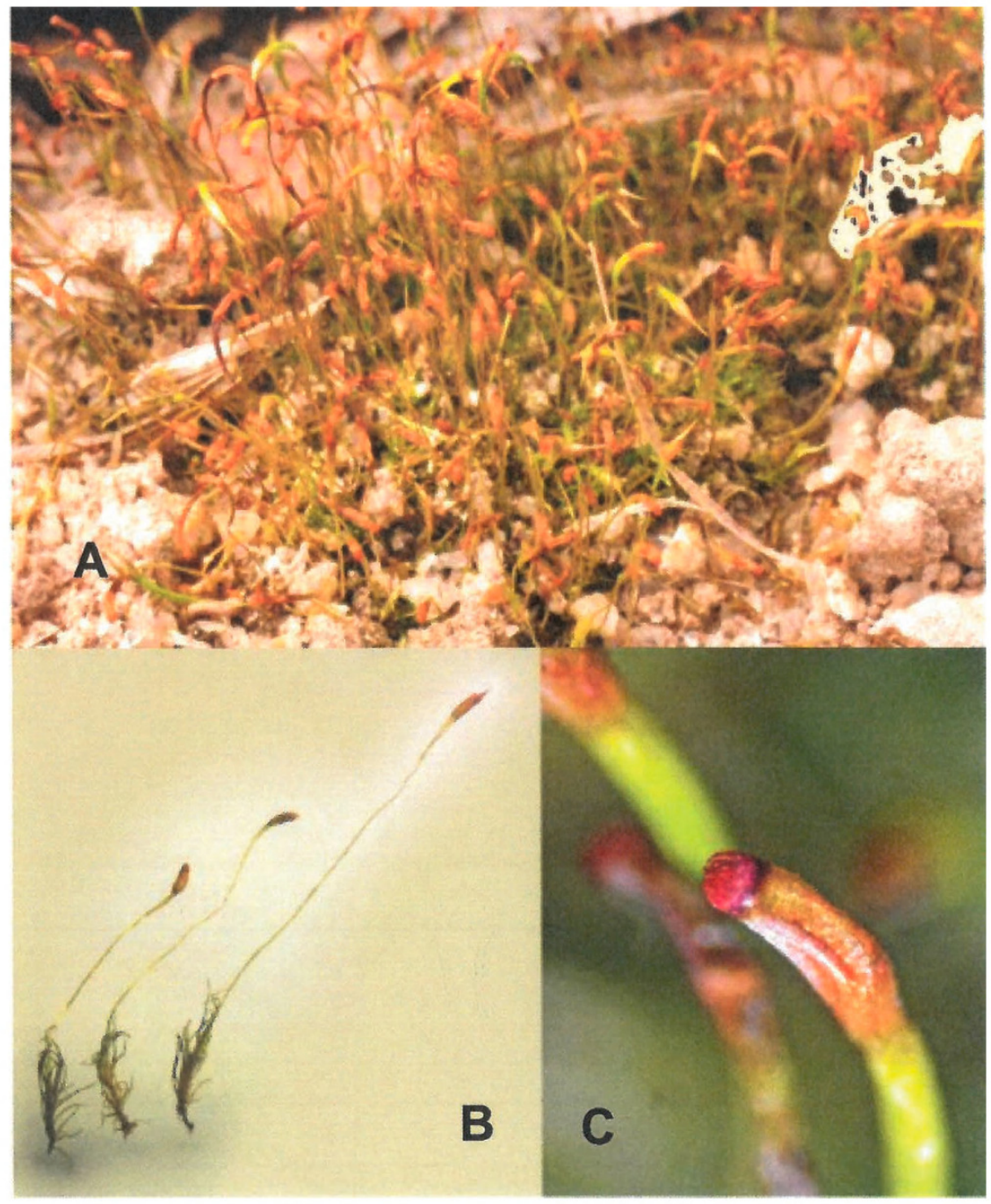

Figure 8. Colour illustrations of T. longicollis. A. Group of plants with sporophytes; B. Three plants with sporophytes: note leaf appearance, range of variation in seta length and neck length in capsule; C. Detail of capsule urn and peristome, and part of the chlorophyllose neck. Illustrations supplied by Andi Cairns and David Meagher of specimen WT-242, on soil under shrub 2.ix.2013 Alligators Nest, Tully Gorge National Park, Queensland.

\section{References}

Atlas of Living Australia (2016) Atlas of Living Australia website at http://www.ala.org.au/Ala.org. Accessed various occasions from 2014 to 2016.

Australia’s Virtual Herbarium (2016) Australia’s Virtual Herbarium website at http://avh.chah.org.au/.Accessed on various occasions from 2014 to 2016.

Bailey FM (1890) Synopsis of Queensland Flora including Phanerogamous and Cryptogamous Plants. Third Supplement (Government Printer, Brisbane).

Bartram EB (1939) Mosses of the Philippines. The Philippine Journal of Science 68: 28-30.

Brotherus VF (1909) Contribution à la flore bryologique de la Nouvelle-Calédoniae. Öfversigt af Finska Vetenskaps-Societetens Förhandlingar 51A(17): 1-31.

Brotherus VF (1911) Contribution à la flore bryologique de La Nouvelle Calédonie III. Öfversigt af Finska Vetenskaps-Societetens Förhandlingar 53A(11): 1-42.

Brotherus VF (1924) Musci In Engler HGA, Prantl KAE (eds) Die Natürlichen Pflanzenfamilien 10: 172-173.

Cao T, Gao C (1988) Studies of Chinese Bryophytes (2). Trematodon Michaux (Musci, Dicranaceae). Journal of the Hattori Botanical Laboratory 65: 323-334.

AusMoss (2017) Catalogue of Australian Mosses (AusMoss) website: http://data.rbg.vic.gov.au/cat/index.php/ mosscatalogue. Accessed on various occasions from 2014 to 2017.

Christy JA (2007) Species Fact Sheet, United States Forest Service (Revised by Candace Fallon February 2011) http://studylib.net/doc/7477995/trematodon-asanoi accessed 20 April 2016. 
Cox CJ, Goffinet B, Wickett NJ, Boles SB, Shaw AJ (2010) Moss Diversity: a molecular phylogenetic analysis of genera. Phytotaxa 9: 175-195.

Crum HA (1994) Bruchiaceae. The Moss Flora of Mexico. Memoirs of the New York Botanic Garden 69: 84-89.

Crum HA, Anderson LE (1981) Mosses of Eastern North America 1. Columbia University Press, New York.

Dowe J, Broughton A (2007) F.M. Bailey's ascent of Mt Bellenden-Ker in 1889, and notes on the publication priority of new vascular plant species from the expedition. Austrobaileya 7: 555-566.

Eddy A (1988) A Handbook of Malesian Mosses. Volume 1 Sphagnales to Dicranales (British Museum of Natural History: London).

Fiz-Palacios O, Schneider H, Heinrichs J, Savolainen V (2011) Diversification of land plants: insights from a familylevel phylogenetic analysis. BMC Evolutionary Biology 11(1): 341 - 341. doi: 10.1186/1471-2148-11-341

Fleischer M (1927) Die Musci der Flora von Buitenzorg. Vol. I - III. (Reprint 1977). J. Cramer Vaduz.

Fritsch R (1991) Index to Bryophyte Counts. Bryophytum Bibliotheca 40: 294-296.

Gangulee HC (1987) Mosses of Eastern India and adjacent regions. 1: 219-233. H. C. Gangulee, Calcutta.

Goffinet B, Buck WR, Shaw AJ (2009) Morphology and Classification of Bryophyta Pp 55-138 In Goffinet B, Shaw AJ (eds) Bryophyte Biology (2 ${ }^{\text {nd }}$ edition). (Cambridge University Press)

Goffinet B, Buck WR, Shaw AJ (2012) Classification of Bryophyta website at http://eeb.uconn.edu/people/ Goffinet/Classificationmosses.html Accessed 7 October 2017.

Iwatsuki Z, Suzuki T (2006) Taxonomic revision of Trematodon asanoi and its related species (Dicranaceae, Musci). Journal of the Hattori Botanical Laboratory 99: 259-269.

Kumar SS (1985) [1987] Taxonomic studies of west Himalayan mosses II. The genus Trematodon. Nova Hedwigia 42: 9-18.

La Farge C, Shaw AJ, Vitt DH (2002) The circumscription of the Dicranaceae (Bryopsida) based on chloroplast regions trnL-trnF and rps4. Systematic Botany 27: 435-452.

Magill RE (1982) Flora of Southern Afric. Bryophyta. Part 1. Mosses. Fascicle 1 Sphagnaceae - Grimmiaceae: 111-117 (Government Printer, Pretoria).

Miller H, Whittier HO, Whittier BA (1978) Prodomus Florae Muscorum Polynesiae. Bryophytorum Bibliotheca 16: 1-334.

Mueller C (1890) Symbolae ad Bryologium Australiae II. Hedwigia 37: 76-171.

Noguchi A (1987) Illustrated Moss Flora of Japan, 1. pp. 134-137. (Hattori Botanical Laboratory, Nichinan).

Norris DH, Koponen T (1990) Bryophyte Flora of the Huon Peninsula, Papua New Guinea XXXV. Dicranaceae and Dicnemonaceae. Acta Botanica Fennica 139: 5-8.

Pursell RA, Reese WD (1982) The mosses reported from New Caledonia. Journal of the Hattori Botanical Laboratory 53: 449-482.

Ramsay HP (2011) Australian Mosses -new chromosome numbers and a compilation of data. Telopea 13: 577-619. https://doi.org/10.7751/telopea20116036

Shaw AJ, Cox CJ, Goffinet B (2005) Global patterns of moss diversity: taxonomic and molecular inferences. Taxon 54: 337-352. https://doi.org/10.2307/25065362

Stone IG (1985) New records of mosses in Australia. Journal of Bryology 13: 475-478. https://doi.org/10.1179/ jbr.1985.13.4.475

Stoneburner A, Wyatt R, Catcheside DG, Stone IG (1993) Census of the mosses of Western Australia. Bryologist 96: 86-101. https://doi.org/10.2307/3243324

Streimann H, Klazenga N (2002) Catalogue of Australian Mosses Flora of Australia series Number 17 (Australian Biological Resources Study, Canberra)

Thouvenot L, Bardat J (2010) Liste actualisée et annotée des mousses de Nouvelle-Calédonie. Cryptogamie Bryologie 31: 163-197. https://doi.org/10.7872/cryb.v34.iss1.2013.37

Thouvenot L, Bardat J (2013) Contribution to the bryophyte flora of New Caledonia 1. New taxa and amendments. Cryptogamie Bryologie 34: 37-47.

Tixier P (1986) Bryophyta exotica VIII. Bryophytes de Nouvelle-Calédonie. Cryptogamie bryologie Lichénologie $7: 225-234$.

Tropicos (2017) TROPICOS Missouri Botanical Garden website at http://www.tropicos.org. Accessed July 2015, April 2016, September 2017.

Watts WW, Whitelegge T (1902) Census Muscorum Australiensium Part 1. Proceedings of the Linnean Society of New South Wales Supplement 27: 31-32.

White CT (1950) Memorial Address: F. M. Bailey, his life and work. Proceedings of the Royal Society of Queensland 61: 104-114.

Zander RH (2007) Flora of North America north of Mexico. Bryophytes: Mosses, part 1.27: pp 433-439. (Oxford University Press, New York.). 


\section{$2 \mathrm{BHL}$ Biodiversity Heritage Library}

Ramsay, Helen P, Seppelt, Rodney D., and Downing, Alison J. 2018. "Trematodon (Bryopsida: Bruchiaceae) in Australia: unravelling the conundrum." Telopea: Journal of plant systematics 21, 101-119. https://doi.org/10.7751/telopea12444.

View This Item Online: https://www.biodiversitylibrary.org/item/282223

DOI: https://doi.org/10.7751/telopea12444

Permalink: https://www.biodiversitylibrary.org/partpdf/305580

\section{Holding Institution}

The Royal Botanic Gardens and Domain Trust, New South Wales, Australia

\section{Sponsored by}

Atlas of Living Australia

\section{Copyright \& Reuse}

Copyright Status: In copyright. Digitized with the permission of the rights holder.

Rights Holder: The Royal Botanic Gardens and Domain Trust, New South Wales, Australia License: http://creativecommons.org/licenses/by-nc-sa/4.0/

Rights: http://biodiversitylibrary.org/permissions

This document was created from content at the Biodiversity Heritage Library, the world's largest open access digital library for biodiversity literature and archives. Visit BHL at https://www.biodiversitylibrary.org. 